\title{
Thinking based Instructional Practices and Academic Achievement of Undergraduate Science Students: Exploring the Role of Critical Thinking Skills and Dispositions
}

\author{
Ghazanfar Ali and Riffat-un-Nisa Awan*
}

Department of Education, University of Sargodha, Pakistan.

\begin{abstract}
Critical thinking (CT) includes skills and dispositions which are closely linked with learning, decision making, problem solving and academic success. Scientific inquiry employs CT in enquiring about and explaining natural phenomenon. However, fostering CT through instruction is still a neglected area in educational institutions. The current study was intended to find out the relationships among critical thinking based instructional practices (CTIPs), critical thinking skills (CTS), critical thinking dispositions (CTD), and academic achievement (AA) of undergraduate students of physics, chemistry, and biological sciences. The study determined the moderating effects of gender, and academic discipline along with mediating effect of CTD and CTS in the relationship between CTIPs and AA. A sample of 320 final year science students of $\mathrm{BS}$ programs, was selected from three selected universities and surveyed through a questionnaire. The results of data analyses revealed gender wise differences in perceived level of CTIPs, CTS and AA in favor of female students. Students of physics were found better in CTS and students of chemistry were found better in academics. Teachers of chemistry were employing CTIPs more frequently than the other departments. The results also revealed that CTIPs had good predictability of CTD of science students while CTS and CTD had significant effects on AA of undergraduates. The results of data analyses had confirmed the significant moderating effects of gender on the relationship between CTD and AA. The moderating effects of gender on the relationship between CTSs and AA of students had been found insignificant. The results showed the insignificant mediating effects of CTS and CTD in the relationship between CTIPs and AA. This study was conducted on cross-sectional descriptive correlational research design; however, the researcher had suggested conducting experimental studies in this area for establishing true causal relationships.

Received | November 06, 2020; Accepted | January 28, 2021; Published | March 15, 2021

*Correspondence | Riffat-un-Nisa Awan, Department of Education, University of Sargodha, Pakistan; Email: riffarukh@gmail.com Citation | Ali, G. and Awan, R.N., 2021. Thinking based instructional practices and academic achievement of undergraduate science students: Exploring the role of critical thinking skills and dispositions. Journal of Innovative Sciences, 7(1): 56-70.

DOI | http://dx.doi.org/10.17582/journal.jis/2021/7.1.56.70

Keywords | Critical thinking skills, Critical thinking dispositions, Instructional practices, Academic achievement, Undergraduate science students
\end{abstract}

\section{Introduction}

Students' academic achievement is one of the most $\boldsymbol{N}$ commonly used criteria for making predictions about personal success. A student's academic progress reflects in the grades or marks that represent the degree to which the educational goals are accomplished. Shoval et al. (2018) defined academic achievement as the degree to which learners benefit from knowledge and skills they acquire during education and training in a given academic discipline or level of education. Students' academic achievement, whether assessed 
in marks or graded in quantitative or qualitatively measures, is the main focus of all stakeholders of the education system (Kahu and Nelson, 2018). In modern education systems, grade point average (GPA) of students is mostly used to indicate the academic performance of students. Many researchers have found a strong and significant relationship between grade point average and academic performance of students (Abbasi, and Izadpanah, 2018; Gelardi and Emby, 2005).

In terms of factors affecting academic achievement, critical thinking has been found the most significant and influential among others (Fong et al., 2017; Vierra, 2014). The researchers have included a range of intellectual abilities and behaviors in the construct of critical thinking comprising evaluation and analysis of arguments and truth claims to understand different perspectives (Ennis, 1985; Lipman, 1988) drawing logical inferences from the given information for problem solving and decision making (Ennis, 1985; Halpern, 1998); asking questions to understand and explain terms, assumptions, and propositions (Halpern, 1998) developing and presenting plausible arguments (Halpern, 1998; Tindal and Nolet, 1995).

Researchers have also recognized the importance of critical thinking dispositions as distinct entities to distinguish critical thinkers from uncritical thinkers beside the actual level of their critical thinking ability (Ennis, 1985). Critical thinking dispositions are the attitudes or habits of mind that keep an individual motivated to respond in a reflective mode. Therefore, the existence of critical thinking dispositions is as much essential as practicing critical thinking skills. American Philosophical Association develops a consensus on these ideal attributes or dispositions of a critical thinker comprising open-mindedness, fair-mindedness, perspective taking, inquisitiveness, flexibility, and the willingness to delay judgment to consider multiple perspectives (Facione, 1990). Educationists have acknowledged that critical thinking skills are essential for meaningful learning, decision making, and problem solving (Kennedy et al., 1991).

There is no doubt a disagreement in the assertion that scientific inquiry employs $\mathrm{CT}$ in enquiring about and explaining natural phenomenon. It shows a close relationship between critical thinking and nature of science to promote a complete understanding of the scientific developments and related global issues (Zeidler et al., 2002; Yacoubian, 2015). Critical thinking has been considered indispensible for developing scientific literacy, democracy and a sense of responsibility in the use and application of scientific developments (Zemplén, 2007; Yacoubian, 2015). Therefore, critical thinking has been integrated into curricula as basic skills and dispositions in science education across the world to develop scientific perspective and global citizenship competence. Especially critical thinking is an integral part of scientific process in asking questions and providing justifications in teaching- learning process of science (Demir, 2015; Yacoubian, 2015; Osborne, 2014).

The researchers that work in this specific field have reported a significant association between critical thinking ability and academic achievement of students (Ghanizadeh and Mirzaee, 2012; Ghazivakili et al., 2014; Hashemi and Ghanizadeh, 2012; King et al., 1990; Ross et al., 2013; Taghva et al., 2014; Vahdat et al., 2012). Many recent studies have confirmed an imperative association between critical thinking and academic performance (Fong et al., 2017; Vierra, 2014). These researchers revealed that critical thinking have a positive impact on academic performance and help students to succeed in the academic field. On the other hand, some of studies have not found any positive or negative impact of critical thinking ability on students' academic performance (Shirrell, 2008). So, previous studies have conflicting results regarding this relationship.

However, fostering critical thinking through instruction is still a neglected area in educational institutions. There is a little representation or practical implications of critical thinking in instructional practices of teachers. The major challenge of educational institutions is to shift the instructional paradigm from teacher-centered instructional approaches to studentcentered approaches (Daud and Husin, 2004). Recent research has identified teaching methods, strategies and techniques that have been found more effective in developing critical thinking among students. Especially, the instructional interventions based on active and collaborative learning strategies have been found more effective in promoting critical thinking among higher education students (Terenzini et al., 1995; Yang and Chou, 2008). These insights have helped instructors to incorporate more effective critical thinking pedagogy in the curriculum of their 
respective academic disciplines (Halpern, 1998).

Empirical research has highlighted the importance of interactive teaching techniques and strategies which enable students to raise questions and evaluate content through logical analysis and comparison. Educators have realized that critical thinking must be practiced as an integral part of the learning content (Snyder and Snyder, 2008). By practicing critical thinking students construct knowledge and understanding in a breadth and depth that is more meaningful, logical and fair. Educational institutions must ensure their students academic success by providing them a conducive learning environment where students are involved in developing and organizing their ideas and concepts by practicing critical thinking (Carr, 1988).

Other instructional practices like providing students with opportunities to work in groups, writing literature review assignments and research reports, preparing and giving class presentations, conducting research projects, and conducting critical thinking based essay exams along with teachers critical feedback, have been found very effective in teaching critical thinking. These instructional practices are effective in provoking students to ask questions and construct answers of the challenging questions being asked by others during discussions and to reflect, analyze and evaluate information instead of superficial recall and description (Owens, 2007; Terenzini et al., 1995). By nature, written assignments provide the best prospect for practicing critical thinking by writing argumentative reviews under the supervision of the instructors. Rewriting assignments to incorporate feedback received from teachers and other students during presentations provide additional support for developing critical thinking (Tsui, 2002). Ruggiero (1988) reveals that direct teaching of thinking skills depends on certain teaching methods instead of what is being taught. The only major change that needs to be made is a paradigm shift in selection of teaching methods. Students' perceptions of teachers' teaching methods also reveal their metacognitive awareness about the interaction of instructional methods and critical thinking abilities (Kember, 1997).

Demographic factors such as age, gender, race, and academic discipline as predictors of critical thinking skills have been studied by many researchers (Aliakbari and Sadeghdaghighi, 2011). Many studies have found that sometimes the level of critical thinking ability of respondents differ due to gender (Ekinci and Aybek, 2010; Kanbay and Okanlı, 2017; Tümkaya et al., 2009; Vierra, 2014) and respective academic discipline (Kanbay and Okanl, 2017; Mahdyeh and Arefi, 2014; Myers and Dyer, 2006; Rodrigues and Oliveira, 2008).

Many research studies had pointed out a complex and dynamic interaction between instructional practices and critical thinking that contributes towards academic performance of higher education students (Moon, 2008; Tuncer and Ozeren, 2012). According to Schraw et al. (2006), the interaction of critical thinking skills and the instructional practices that promote critical thinking significantly contribute towards academic achievement.

This study was intended to provide theoretical insights and practical implications of the interplay of critical thinking based instructional practices, critical thinking skills, critical thinking dispositions, and academic achievement of science students at higher education level. It would be significantly helpful for updating understanding of theorists, practitioners and policy makers by offering the empirical evidence about the current situation of the relationships between critical thinking based instructional practices, critical thinking skills, critical thinking dispositions, and academic achievement of science students at university level in Pakistani context. Similarly, it could be helpful for curriculum developers, and administrators to implement student centred instructional designs in educational programs to inculcate critical thinking among students.

Therefore, the main purpose of this research was to find out the relationships among critical thinking based instructional practices, critical thinking dispositions, critical thinking skills, and academic achievement of students in natural sciences at university level. Furthermore, the moderating role of demographic variables of gender and academic discipline on the correlation between critical thinking based instructional practices and academic achievement was determined. This study also determined the mediating effect of critical thinking skills and dispositions of science students in the correlation between critical thinking based instructional practices and academic achievement. Moreover, the predictive power of critical thinking skills, dispositions, instructional practices which promote critical thinking, and 
gender as predictors had been explored to predict the academic achievement of natural sciences students.

\subsection{Objectives of the study}

The study intends to:

1. Assess level of and association among critical thinking dispositions, critical thinking skills, critical thinking based instructional practices in science education and academic achievement of students of natural sciences at university level.

2. Assess the group differences based on gender and academic disciplines (departments) in critical thinking skills, critical thinking based instructional practices, critical thinking dispositions and academic achievement of science students.

3. Predict the academic achievement using critical thinking based instructional practices, critical thinking dispositions and skills as independent variables.

4. Measure the moderating effect of gender and discipline on the relationship among critical thinking based instructional practices, critical thinking skills and dispositions and academic achievement.

5. Find out whether the critical thinking skills and dispositions mediate the relationships between critical thinking based instructional practices and academic achievement.

\subsection{The hypotheses of the study}

The researcher has formulated following main research hypotheses for this study:

$\mathrm{H}_{1}$ : There are significant positive relationships among critical thinking skills, dispositions, critical thinking based instructional practices, and academic achievement of natural sciences students.

$\mathrm{H}_{2}$ : There is significant positive effect of critical thinking based instructional practices, critical thinking skills and dispositions on academic achievement of natural sciences students.

$\mathrm{H}_{3}$ : There are significant group differences based on gender and discipline in critical thinking skills, dispositions, critical thinking based instructional practices and academic achievement of science students.

$\mathrm{H}_{4}$ : There is significant moderating effect of gender, and discipline on the relationship among critical thinking based instructional practices, critical thinking skills, critical thinking dispositions and academic achievement.

$\mathrm{H}_{5}$ : There is significant mediating effect of critical thinking skills and dispositions in the relationships between critical thinking based instructional practices and academic achievement of science students.

\subsection{Research model}

Following Figure 1 presents in simplified form the theoretical framework employed in the research model:

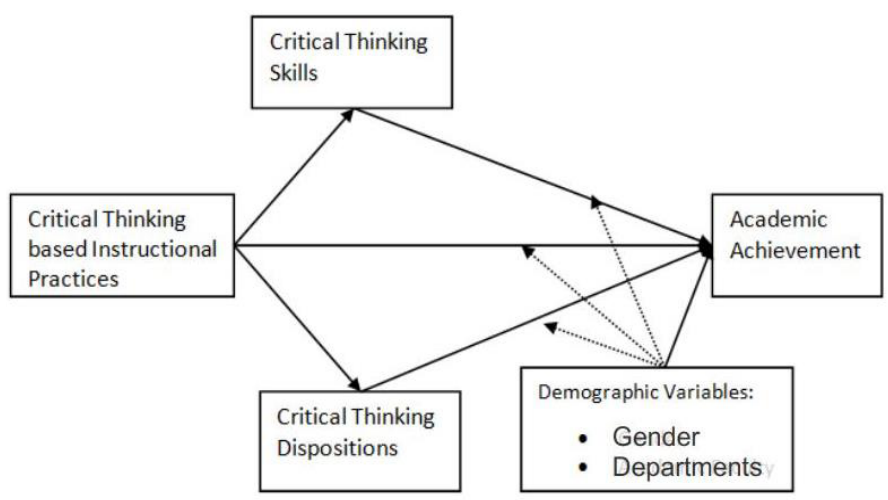

Figure 1: Theoretical research model of the study.

As shown in Figure 1 critical thinking based instructional practices, critical thinking dispositions, and skills were the main independent variables (predictors) and academic achievement of university students was the dependent variable (outcome/ criterion) of this study. Gender and academic discipline of the respondents were the main moderator variables in the conceptual framework. Further, critical thinking skills and dispositions were the mediator variables in the correlation between critical thinking based instructional practices and academic achievement of science students in conceptual framework of this study.

\section{Materials and Methods}

\subsection{Research design}

The nature of the research study called for a crosssectional descriptive correlational research design.

\subsection{Population and sample}

All the higher education students of the faculty of sciences studying in the general public sector universities of the Punjab province were the target population of the study. All the higher education students of sciences studying in three randomly selected general public sector universities of province Punjab were the accessible population of this study.

According to HEC official website there were 
27 general public universities in province Punjab. From the list of these 27 general universities three universities including University of Sargodha, University of the Punjab, and Bahauddin Zakariya University were randomly selected. From these three universities, three academic departments (Physics, chemistry and biological sciences) of the faculty of science were selected conveniently.

Within each academic department students were categorized on the basis of their seniority. Senior students (final year students) were assumed to have a better understanding of their educational dynamics and could express their experiences more clearly and precisely. Therefore, one intact group of final year students of BS science programs was selected purposively from each of the selected academic departments and all available students of that group were surveyed. Therefore, a sample of 320 final year science students of BS program was selected from University of Sargodha, University of the Punjab, and Bahauddin Zakariya University.

\subsection{Research instruments}

A questionnaire was developed comprising scales of key variables of the study along with demographic variables.

\subsubsection{Critical thinking skills test}

The Critical Thinking Skills Test (CTST) is consisted of items adapted from some eminent tests of critical thinking skills and takes less time to complete than other measures. The CTST is generic in nature i.e. it intends to take critical thinking in its general sense of the term. CTST has further five dimensions that have been derived from the Watson-Glaser Critical Thinking Assessment manual (Watson and Glaser, 1980) including recognition of assumptions, inference, deduction, interpretation, and evaluation of arguments. The CTST has adapted items from available critical thinking tests to make the test culturally fair for undergraduate level students of sciences. The CTST is consisted of 43 -item that measure critical thinking skills on multiple-choice format. Each item has only one correct answer. In the perspective of the current study, this test was used to provide an overall level of achieved Critical Thinking skills of the respondents of the study.

\subsubsection{Critical thinking disposition scale}

This study adapted Critical Thinking Disposition
Scale developed by a group of researchers from the University of Florida (Ricketts, 2003). The major constructs or subscales of this instrument were engagement, cognitive maturity, and innovativeness.

\subsubsection{Critical thinking based instructional practices scale} The researchers developed a rating scale that measure the level of representation of critical thinking based instructional practices (CTIPs) of teachers through students' perceptions. The researchers developed a self-report scale to find out students perceptions about frequency of occurrences of active and collaborative learning strategies in their teachers' instructional practices.

First of all, the items were developed to represent a sample of different instructional practices (specific teaching activities that guide interaction during teaching learning process.) used by the instructors at university level to promote and develop critical thinking among students. These instructional practices include questioning, discussion, project work (written assignments and presentations), assessment practices and other miscellaneous constructivist teaching methods and techniques that are generally recommended and practiced in science education.

\subsubsection{Academic achievement}

The students' current CGPA scores were used to represent the academic achievement of higher education students.

\subsection{Pilot study of the instruments}

The composite questionnaire, measuring all the variables of the study, was exposed to pilot testing for validation purposes. It was given to 30 students from natural sciences $10 \%$ of the sample for this purpose. Any language or context related difficulties faced by the respondents, if detected, were removed to facilitate the respondents. Cronbach's alpha was calculated for all the scales (Cronbach, 1951) to estimate about the internal consistency of the scales.

\subsection{Data collection}

The complete questionnaires were distributed to the student in person and were collected by the researcher at the spot. Out of 350 distributed questionnaires, 320 were found in usable form with a response rate of $91.4 \%$. 


\section{Results and Discussion}

After the data collection was complete, data was entered with codes in IBM SPSS 22 data editor for analyzing each construct. Descriptive statistics, $t$-test, ANOVA, Pearson $r$, regression analysis and Process Macro were used to analyse.

As revealed in the Table 1 the average academic achievement of university science students is about 3.19 with a standard deviation of 0.383 which is relatively high. The variables critical thinking skills, instructional practices and critical thinking dispositions revealed relatively high means which were higher than median values. The kurtosis and skewness of almost all of the variables were either lesser than or close to the \pm 1.0 . This is quite good regarding the distribution of these variables. It also demonstrated significant level of normality for these variables as far as skewness and kurtosis are concerned. Trend mean analysis of critical thinking dispositions revealed that science students in this study had higher levels of critical thinking dispositions. Similarly trend mean analysis of critical thinking based instructional practices revealed in students perceptions about the overall level of representation of interactive and constructivist instructional practices is sufficiently high at university level.
Table 2 shows positive and significant correlation of critical thinking skills with critical thinking dispositions $(r=.158, \quad p<.01)$ and academic achievement $(r=.474, p<.01)$. It further reveals positive and significant correlation of critical thinking dispositions with instructional practices $(r=.166, p<$ $.01)$ and academic achievement $(r=.122, p<.05)$.

Table 3 indicated that $t$-value was significant for critical thinking skills $t(317)=-3.046, \mathrm{p}=.003$, instructional practices $t(317)=-4.110, \mathrm{p}=.000$, and academic achievement $t(317)=-5.969, \mathrm{p}=.000$. It was determined that there existed significant gender differences in students' critical thinking skills and their achievement and teachers' instructional practice and females were having high means as compared to male students.

The Table 4 indicates that $F$-values were significant for critical thinking skills $F(2,318)=15.76, \mathrm{p}=0.000$, and academic achievement $F(2,318)=19.57, \mathrm{p}=0.000$. The other two comparison were non-significant.

LSD test revealed significant group differences in the critical thinking skills of students of physics as they were having higher means as compared to the students of chemistry and biological sciences. Furthermore, it was evident that teachers of chemistry department

Table 1: Descriptive statistics of key variables and sub scales.

\begin{tabular}{|c|c|c|c|c|c|c|c|}
\hline Variables & Mean & Trend mean & SD & Median & Skewness & Kurtosis & $\alpha$ \\
\hline Critical thinking skills & 25.39 & & 3.57 & 25 & .154 & -.078 & 0.78 \\
\hline Argument & 4.96 & & 1.17 & 5 & -.038 & -.154 & \\
\hline Assumption & 4.49 & & 1.298 & 5 & -.160 & -.154 & \\
\hline Deduction & 5.77 & & 1.410 & 6 & -.252 & -.204 & \\
\hline Interpretation of information & 4.92 & & 1.458 & 5 & -.317 & -.281 & \\
\hline Inference & 5.25 & & 1.628 & 5 & -169 & -.124 & \\
\hline Critical thinking dispositions & 94.02 & 3.73 & 14.32 & 93 & -.157 & -.070 & 0.89 \\
\hline Cognitive maturity & 26.50 & 3.78 & .619 & 26 & -.400 & .359 & \\
\hline Engagement & 41.31 & 3.75 & .609 & 41 & -.208 & .127 & \\
\hline Innovation & 26.14 & 3.71 & .752 & 26 & -.388 &.-069 & \\
\hline Instructional practice & 124.06 & 3.35 & .618 & 124 & -.092 & -.318 & 0.93 \\
\hline Questioning & 20.83 & 3.47 & .741 & 21 & -.340 & -.422 & \\
\hline Discussion & 23.03 & 3.29 & .835 & 22 & -.143 & -.491 & \\
\hline Project work & 26.96 & 3.37 & .729 & 27 & -.090 & -.453 & \\
\hline Miscellaneous constructivist practices & 23.80 & 3.39 & .841 & 24 & -.298 & -.295 & \\
\hline Problem based instruction & 13.24 & 3.31 & .822 & 14 & -.145 & -.246 & \\
\hline Assessment practices & 16.15 & 3.23 & .763 & 16 & -.009 & -.256 & \\
\hline Academic achievement & 3.19 & & 0.383 & 3.21 & -.308 & -.347 & \\
\hline
\end{tabular}


were employing better instructional practices for improving critical thinking in students and their students were better in their achievement as compared to other departments of science faculty.

Table 2: Correlation of variables of study.

\begin{tabular}{llllll}
\hline $\begin{array}{l}\text { Sr. } \\
\text { No }\end{array}$ & $\mathbf{1}$ & $\mathbf{2}$ & $\mathbf{3}$ & $\mathbf{4}$ \\
\hline 1 & Critical thinking skills & 1 & $.158^{* *}$ & .066 & $.474^{* *}$ \\
2 & Critical thinking dispositions & $.158^{* * *}$ & 1 & $.168^{* *}$ & $.124^{*}$ \\
3 & Instructional practice & .066 & $.168^{* *}$ & 1 & .038 \\
4 & Academic achievement & $.474^{* * *}$ & $.124^{* *}$ & .038 & 1 \\
\hline **, Significant at the 0.01 level; *, Significant at the 0.05 level \\
(2-tailed).
\end{tabular}

The results reported in the Table 5 reveals that the demographic variables i.e. respondents' discipline and university had insignificant effects on critical thinking skills, critical thinking dispositions and academic achievement of the students. However, gender had significant effects of on critical thinking skills $(\beta=$ $0.169, \mathrm{p}<.003)$ and academic achievement $(\beta=0.318, \mathrm{p}$ $<.001)$. Therefore, all these demographic variables were taken as statistical control variables on the relationships between the predictor and dependent variables.

The results shown in Table 5 reveals that critical thinking based instructional practices (CTIPs) acted as a significant predictor $(\beta=.168, p=.003)$ for science students' critical thinking dispositions (CTD) in this study. This significant positive relationship between CTIPs and AA indicates that using critical thinking based instructional practices increases the university students' academic achievement in our sample.

Table 3: Independent sample $t$ test for gender difference of all variables.

\begin{tabular}{lllllllll}
\hline SN & Variables & Gender & $\mathbf{N}$ & Mean & Std & t & Sig. & Mean Diff \\
\hline 1 & Critical thinking skills & Male & 115 & 24.59 & 3.86 & -3.046 & .003 & -1.251 \\
& & Female & 204 & 25.84 & 3.32 & & & \\
2 & \multirow{2}{*}{ Critical thinking dispositions } & Male & 115 & 94.17 & 15.29 & .204 & .838 & .342 \\
& & Female & 204 & 93.83 & 13.79 & & & \\
3 & \multirow{2}{*}{ Instructional practices } & Male & 115 & 117.17 & 24.76 & -4.110 & .000 & -10.71 \\
& \multirow{3}{*}{ Academic achievement } & Female & 204 & 127.87 & 20.86 & & & \\
& & Male & 115 & 3.03 & 0.38 & -5.969 & .000 & -.253 \\
& & Female & 204 & 3.28 & 0.35 & & & \\
\hline
\end{tabular}

Table 4: One-way ANOVA comparing variables by departments of science faculty.

\begin{tabular}{|c|c|c|c|c|c|c|}
\hline & & SS & df & MS & $\mathbf{F}$ & Sig. \\
\hline \multirow{3}{*}{$\begin{array}{l}\text { Critical thinking } \\
\text { skills }\end{array}$} & Between groups & 367.832 & 2 & 183.916 & \multirow[t]{3}{*}{15.766} & \multirow[t]{3}{*}{.000} \\
\hline & Within groups & 3686.187 & 316 & 11.665 & & \\
\hline & Total & 4054.019 & 318 & & & \\
\hline \multirow{3}{*}{$\begin{array}{l}\text { Critical thinking } \\
\text { dispositions }\end{array}$} & Between groups & 202.326 & 2 & 101.163 & \multirow[t]{3}{*}{.491} & \multirow[t]{3}{*}{.612} \\
\hline & Within groups & 64679.055 & 314 & 205.984 & & \\
\hline & Total & 64881.382 & 316 & & & \\
\hline \multirow{3}{*}{$\begin{array}{l}\text { Instructional prac- } \\
\text { tices }\end{array}$} & Between groups & 2386.201 & 2 & 1193.101 & \multirow[t]{3}{*}{2.295} & \multirow[t]{3}{*}{.102} \\
\hline & Within groups & 164243.749 & 316 & 519.759 & & \\
\hline & Total & 166629.950 & 318 & & & \\
\hline \multirow{3}{*}{$\begin{array}{l}\text { Academic achieve- } \\
\text { ment }\end{array}$} & Between groups & 5.145 & 2 & 2.573 & \multirow[t]{3}{*}{19.574} & \multirow[t]{3}{*}{.000} \\
\hline & Within groups & 41.529 & 316 & .131 & & \\
\hline & Total & 46.674 & 318 & & & \\
\hline
\end{tabular}

Table 4.1: LSD Post Hoc test comparing variables by departments of science faculty.

\begin{tabular}{llllll}
\hline Factors & (I) Department & (J) Department & Mean Difference (I-J) & Std. Error. & Sig \\
\hline Critical thinking skills & Physics & Biological sciences & $1.761^{*}$ & .488 & .000 \\
& Physics & Chemistry & $2.479^{*}$ & .449 & .000 \\
Instructional practices & Chemistry & Physics & 5.862 & 3.00 & .050 \\
Academic achievement & Chemistry & Biological Sciences & $.199^{*}$ & 0.052 & 0.000 \\
& Chemistry & Physics & $.294^{*}$ & 0.048 & 0.000 \\
\hline
\end{tabular}

Journal of Innovative Sciences

June 2021 | Volume 7 | Issue 1 | Page 62 
Table 5: Results regarding hypothesized relationships among predictors, moderators and criterion variables.

\begin{tabular}{|c|c|c|c|c|}
\hline \multirow[t]{2}{*}{ Sr. No. } & \multirow[t]{2}{*}{ Control, independent and moderating variables } & \multicolumn{3}{|c|}{ Dependent variables (Standardized Betas, $\beta$ ) } \\
\hline & & $\begin{array}{l}\text { Critical thinking } \\
\text { skills (CTS) }\end{array}$ & $\begin{array}{l}\text { Critical thinking } \\
\text { dispositions }\end{array}$ & $\begin{array}{l}\text { Academic } \\
\text { achievement }\end{array}$ \\
\hline 1 & Control variables: Gender & $0.169(0.003)^{\mathrm{a}}$ & $-0.012(0.838)$ & $0.318^{\mathrm{b}}(0.000)$ \\
\hline 3 & Discipline & $-0.093(0.098)$ & $-0.030(0.594)$ & $-0.091(0.103)$ \\
\hline 4 & University & $-0.082(0.146)$ & $-0.086(0.126)$ & $-0.065(0.250)$ \\
\hline 5 & $\begin{array}{l}\text { Independent variables: Critical thinking } \\
\text { instructional practices }\end{array}$ & $0.066(0.239)$ & $0.168(0.003)$ & $0.038(0.502)$ \\
\hline 6 & Critical thinking skills & & & $0.474(0.000)$ \\
\hline 7 & Critical thinking dispositions & & & $0.124(0.027)$ \\
\hline 8 & Moderating/interaction effects: Gender *ctips & & & $-0.003(0.135)$ \\
\hline 9 & Gender *ctss & & & $-0.001(0.916)$ \\
\hline 10 & Gender *ctds & & & $-0.007(0.017)$ \\
\hline 11 & Discipline* ctips & & & $0.002(0.519)$ \\
\hline 12 & Discipline *ctss & & & $-0.012(0.376)$ \\
\hline 13 & Discipline *ctds & & & $-0.018(0.591)$ \\
\hline 14 & $\mathrm{R}^{2}$ & 0.004 & 0.028 & 0.001 \\
\hline
\end{tabular}

a, The p-values are given in the parentheses; b, The significant effects are presented in bold.
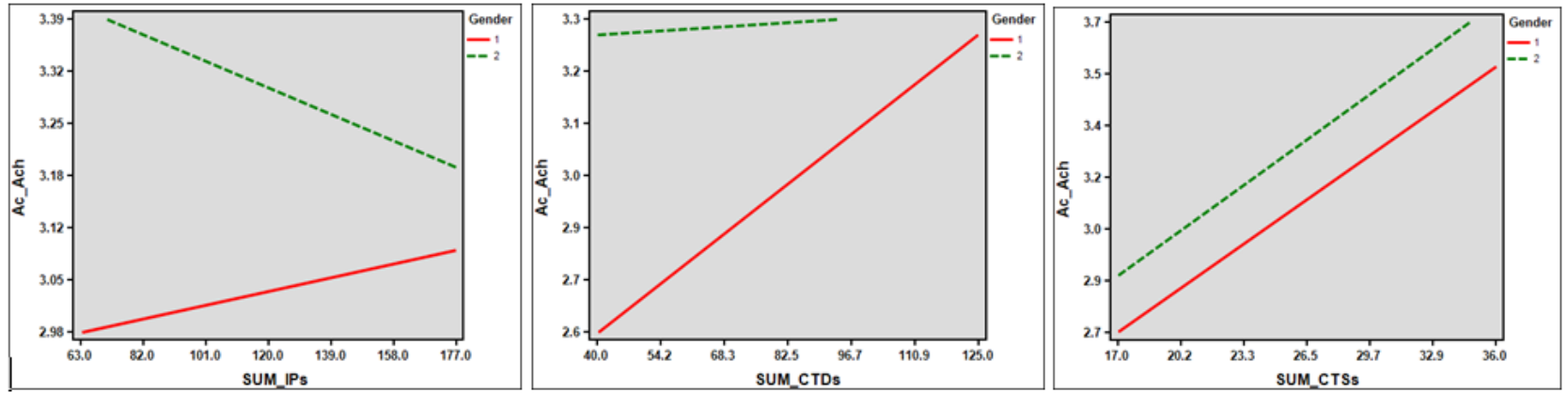

Figure 2: Interaction effects for gender with independent and dependent variables.

The direct effects of CTIPs on critical thinking skills (CTS) and academic achievement (AA) were found insignificant which means that perceptions about the level of representation of CTIPs had no effect on science students' critical thinking skills and academic achievement in this sample. The results shown in Table 5 reveals that the effects of CTS $(\beta=.474, p=.000)$ and CTD $(\beta=.124, p=.027)$ were found significant for science students' academic achievement.

As far as the moderating effect of gender on the relationship between critical thinking based instructional practices and university students' academic achievement is concerned, the results reported in Table 5, reveals that the interaction of gender with critical thinking based instructional practices $\left(\right.$ Gender ${ }^{*}$ CTIPs $)(\beta=-0.003$ and $p<.135)$ and gender with critical thinking skills (Gender ${ }^{*}$ CTSs $)(\beta=-0.001$ and $p<.916)$ had insignificant effects on students' academic achievement. However, the interaction of gender with critical thinking dispositions (Gender ${ }^{*} \mathrm{CTD}$ ) had significant effect on students' academic achievement $(\beta=-0.007, \mathrm{p}<$ .017)

The interaction of academic discipline with all independent variables of the study had insignificant effects on students' academic achievement revealing that academic discipline did not moderate the relationship between independent variables and dependent variables.

All interaction effects reported in Table 5 are graphically portrayed in the following figures. The interaction of gender with CTIPs, CTSs, CTDs and AA are illustrated in the Figure 2. Furthermore, the interaction of departments with CTIPs, CTSs, CTDs and $\mathrm{AA}$ are illustrated in the Figure 3. 

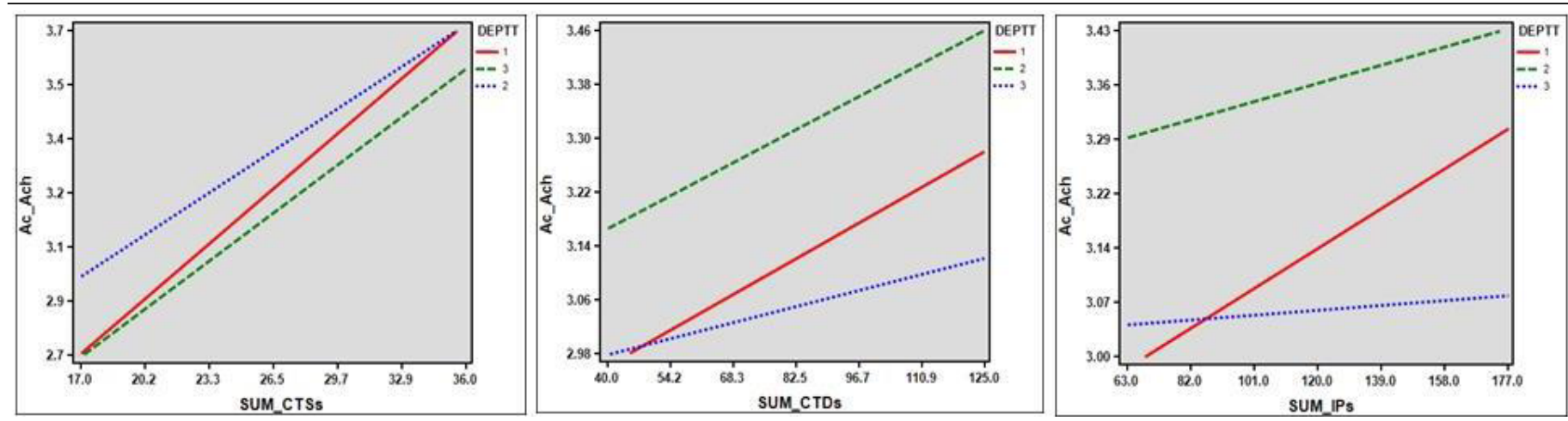

Figure 3: Interaction effects for departments with independent and dependent variables.

Table 6: Direct and mediating effects of critical thinking skills and critical thinking dispositions on relationship between critical thinking based instructional practices and academic achievement.

\begin{tabular}{lllll}
\hline Sr. No. & Mediated relationships & Standardized Beta, $\boldsymbol{\beta}$ & $\mathbf{9 5 \%}$ CI (L.L. - U.L.) & (p-value) \\
\hline \multirow{2}{*}{1} & Direct effect & & & \\
& CTIPs $\rightarrow$ AA & .038 & $(-.0014-.0019)$ & 0.502 \\
& Indirect effect & & & \\
3 & CTIPs $\rightarrow$ CTS $\rightarrow$ AA & 0.0293 & $(-.0226-.0815)$ & n.s \\
& CTIPs $\rightarrow$ CTD $\rightarrow$ AA & 0.0079 & $(-.0103-.0299)$ & n.s \\
& Total effect & & & \\
& CTIPs $\rightarrow$ AA + CTIPs $\rightarrow$ CTS $\rightarrow$ AA + & .0009 & $(-.0011-.0027)$ & 0.352 \\
& CTIPs $\rightarrow$ CTD $\rightarrow$ AA & & & \\
\hline
\end{tabular}

Note: CTIPs, critical thinking based instructional practices; CTD, critical thinking dispositions; CTS, critical thinking skills; AA, academic achievement.

Table 6 shows the direct, indirect and total effect due to mediation of critical thinking skills and dispositions in the relationship between critical thinking based instructional practices of science faculty members as perceived by the students and their academic achievement. The results showed insignificant positive indirect effect of CTIPs on AA $\beta=.0293,95 \% \mathrm{CI}=$ $(-.0226, .0815)$ when mediated by CTSs and again insignificant indirect effect of CTIPs on AA $\beta=$ $.0079,95 \% \mathrm{CI}=(-.0103, .0299)$ when mediated by CTDs. Overall insignificant results of direct effect $(\beta=.038, p<.005)$ and insignificant indirect effects indicated no mediation of CTSs and CTDs in the correlation between CTIPs and AA at $\mathrm{p}<.05$. All these effects are reflected in the following Figure 4.

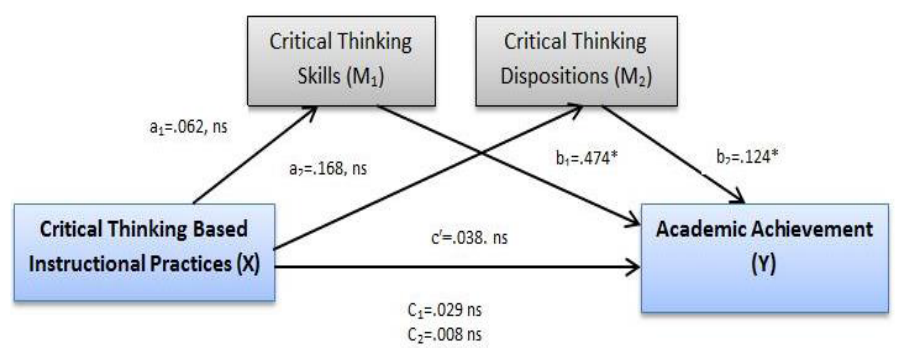

Figure 4: Direct $\left(c^{\prime}\right)$ and Indirect Paths $(c)$ of the study variables.
This study showed that there were significantly positive relationships among critical thinking skills, dispositions, interactive critical thinking based instructional practices and academic achievement of undergraduate science students. These findings are quite consistent with other studies conducted on this topic as discussed below, although it is rare for a single study to explore the interactions of these variables simultaneously.

These results were consistent with many studies that established positive relationship between critical thinking dispositions and academic achievement (Ekinci and Aybek, 2010; Kanbay and Okanll, 2017; Tümkaya et al., 2009; Vierra, 2014); critical thinking skills and academic achievement (Abbasi and Izadpanah, 2018; Fong et al., 2017; Ghanizadeh, 2017; Hashemi and Ghanizadeh, 2012; Ross et al., 2013; Taghva et al., 2014; Vierra, 2014) and the effects of different interactive instructional practices on outcomes of critical thinking and academic achievement (Snyder and Snyder, 2008; Yang and Chou, 2008). These researchers found that critical thinking have a positive impact on academic performance and help students to succeed in their 
academic field.

The results of current study revealed that instructional practices had significant positive effect on critical thinking dispositions, skills and academic achievement of science students. These results are similar and consistent with other studies that pointed out a positive significant effect of critical thinking based instructional practices on critical thinking and academic achievement of students (Gibbs and Coffey, 2004; Moon, 2008; Schraw et al., 2006; Tuncer and Ozeren, 2012).

Results also revealed that critical thinking (both skills and dispositions) insignificantly mediated the relationship between critical thinking based instructional practices and academic achievement of students. This results were not consistent with the recent studies that pointed out a positive indirect effect of critical thinking based instructional practices on academic performance of higher education students through critical thinking (Gibbs and Coffey, 2004; Moon, 2008; Schraw et al., 2006; Tuncer and Ozeren, 2012).These studies strengthened the notion that critical thinking may act as an underlying linking mechanism between instructional practices that promote critical thinking and academic achievement of students.

A large number of studies have found that sometimes the level of critical thinking ability of respondents differs due to gender. These studies have found that there is relationship between gender and critical thinking ability (Gelen, 2002; Yeh, 1997). Some of them provide a contradictory picture in favor of men concluding that boys have higher level of critical thinking skills than those of girls (King et al., 1990).

On the contrary, in many studies, researchers have not found any significant difference between men and women in this regard (Myers and Dyer, 2006; Vahdat et al., 2012). They concluded that male and female students have comparable level of critical thinking abilities. In addition, the study conducted by Grant (2003) has discovered that the interaction between gender and critical thinking skills of students had no effect on their academic performance. Another study conducted by Ben et al. (2000) also supported this interaction concluding that gender has significant moderating effect on the correlation between critical thinking skills and academic achievement of students.
The results of these studies have also revealed that critical thinking dispositions do not change due to gender. Similar to this result, Ekinci and Aybek (2010), Jenkins and Walker (2014), and Tümkaya et al. (2009) found that there is no gender difference in the critical thinking dispositions of higher education students.

However, findings of some studies support female students for having better critical thinking dispositions than males (Zayif, 2008). Research has shown that the critical thinking dispositions of respondents improve academic performance, and vice versa. Due to different samples and cultural background, there may be conflicts between these studies.

Myers and Dyer (2006) found that academic discipline significantly moderated the correlation between critical thinking skills and academic performance. According to their study critical thinking skills of science students is positively correlated with academic performance whereas critical thinking skills of arts students is negatively correlated with academic performance. These findings are consistent with Rodrigues and Oliveira (2008), who claimed that physics is a scientific discipline that supports the development of critical thinking skills among students. Myers and Dyer (2006) have found that respondents' academic discipline significantly moderated the correlation between critical thinking skills and academic performance. According to their study critical thinking ability of science students is positively correlated with academic performance. These findings are consistent with Rodrigues and Oliveira (2008), who claimed that physics is the scientific discipline that supports the development of critical thinking skills among students.

Recent research has highlighted the importance of critical thinking as an educational outcome that has become the need of modern society (Forst, 1997). Findings of this study supported by other studies have put emphasis on teachers, administrators, and curriculum planners to incorporate critical thinking based instructional practices in curriculum and instruction in their respective domains.

\section{Conclusions and Recommendations}

The data analysis revealed that critical thinking skills had a significant and positive association 
with critical thinking dispositions and academic achievement of science students. While instructional practices promoting critical thinking had a significant and positive association with critical thinking dispositions. Gender wise comparisons revealed that female students' performance was higher than male students regarding academic achievement and critical thinking skills and their perceived level of critical thinking based instructional practices was also higher than male students.

Discipline wise comparisons revealed that physics students' performance was higher than the students of chemistry and biological sciences regarding critical thinking skills. While the perceived level of critical thinking based instructional practices of chemistry students was higher than physics students revealing that teachers of chemistry department were employing better instructional practices for improving critical thinking in students and their students were better in their achievement as compared to other departments of science faculty.

Gender had significant moderating role in determining the relationships between critical thinking based instructional practices and academic achievement of science students. It means that female students showed higher academic achievement than males when exposed to higher levels of critical thinking based instructional practices. Similarly, gender had significant moderating effect on the relationships between critical thinking dispositions and academic achievement of university students. It means that male science students exhibiting higher levels of critical thinking dispositions perform better than female science students in terms of academic achievement. However, gender had insignificant moderating effect on the relationships between critical thinking skills and academic achievement of science students. It means that male and female university students exhibit insignificant differences in their academic achievement if they perform at the same levels of critical thinking skills. Academic discipline had insignificant moderating role in determining the relationships between independent variables and academic achievement of science students

Mediation effect of critical thinking skills was verified for instructional practices and students' academic achievement. However, mediating role of critical thinking disposition for instructional practices and students' academic achievement was not verified.

\section{Implications}

The present study was conducted to determine the role of critical thinking based instructional practices, critical thinking skills and critical thinking dispositions as predictors of academic achievement of undergraduate science students at university level in Pakistan. It proposed a conceptual framework containing an underlying mechanism of networked relationships among constructs to predict students' academic achievement. The findings highlighted the fact that link between critical thinking based instructional practices and critical thinking (skills and dispositions) closely and deeply contribute towards academic achievement of higher education students.

The results of this study put forward an empirical account of the current situation of the usage of critical thinking based instructional practices and their relationships with critical thinking skills, critical thinking dispositions, and academic achievement of science students at university level in Pakistani context. These findings had highlighted that university teachers need to improve instructional practices by adapting an interactive constructivist approach towards teaching and learning to foster the critical thinking among science students. In this regard the importance of student-centered instructional approaches had especially been emphasized to enhance the level of critical thinking and academic achievement of higher education students.

These findings of the study also provided theoretical and practical insights for theorists, practitioners curriculum developers, administrators and policy makers to improve the current level of critical thinking training by implementing student centred instructional designs in educational programs of universities in Pakistan and the higher education science instructors should reconsider their instructional practices for improving critical thinking of their students in Pakistan.

However, instructional practices are not the only conditions that affect critical thinking and academic performance of higher education students. Other contextual and personal factors should also be explored to understand and improve the dynamics of these variables. Regarding this, one useful strategy might be providing conducive teaching and learning 
environment that support the integration of critical thinking skills and dispositions in curriculum and instruction.

In this study moderating effects of gender and academic disciplines (physics, chemistry and biological sciences) on the relationship between independent variables (critical thinking based instructional practices, critical thinking skills and dispositions) and dependent variable (academic achievement) had been explored. However, further research is required to determine whether the male/ female and sciences/ social sciences student have the same or different pattern of interaction of the studied variables through multi-group modeling.

The researcher sampled 320 science students from three universities of the Punjab province, the parameters of the generalizability should be enhanced by replicating the study with larger and heterogeneous samples. As mentioned earlier a crosssectional descriptive correlational research design was employed in this study. This design is not sufficient to address causal relations and developments in students' critical thinking skills and dispositions over a period of time. So it was strongly recommended for future studies to use experimental and longitudinal research designs with more inclusive sets of predictors.

This study was delimited to some perceived factors that were related to critical thinking and academic achievement of undergraduate science students, knitted in the framework of student-centered instructional approaches in literature. The future research may study more closely the educational, personal, and cultural factors as predictors of critical thinking and academic achievement of higher education students with a more heterogeneous Pakistani sample.

The researcher also realized the importance of cross cultural studies on this topic. A definite need was, therefore, felt for a series of systematic comparative studies across cultures on the dynamics of critical thinking based instructional practices, critical thinking and academic achievement at different levels of education.

\section{Novelty Statement}

This study had highlighted the need to improve in- structional practices of science teachers to develop and foster the critical thinking in undergraduate science students. In this regard the current status of the use of student-centered instructional approaches in science teaching had especially been highlighted in relation to the current level of critical thinking and academic achievement of science students.

\section{Author's Contribution}

Ghazanfar Ali: Research planning, collection of data and paper writing.

Riffat-un-Nisa Awan: Corresponding Author, Statistical analysis of data and proof reading of research article.

Conflict of Interest

The authors have declared no conflict of interest.

\section{References}

Abbasi, A. and Izadpanah, S., 2018. The relationship between critical thinking, its subscales and academic achievement of English language course: the predictability of educational success based on critical thinking. Academy Journal of Educational Sciences, 2(2): 91-105. https://doi. org/10.31805/acjes.445545

Aliakbari, M. and Sadeghdaghighi, A., 2011. Investigation of the relationship between gender, field of study, and critical thinking skill: The case of Iranian students. In Proceedings of the $16^{\text {th }}$ Conference of Pan-Pcific Association of Applied Linguistics 301-310.

Ben, Ron, S. and Zoller, U., 2000. The disposition of eleventh-grade science students toward critical thinking. Journal of Science Education and Technology, 9(2): 149-159. https://doi. org/10.1023/A:1009474023364

Carr. 1988. Knowledge and curriculum: Four dogmas of childcentred education. Journal of Philosophy of Education, 22(2): 151-162. https:// doi.org/10.1111/j.1467-9752.1988.tb00188.x

Cronbach, L.J. 1951. Coefficient alpha and the internal structure of tests. Psychometrika, 16(3): 297-334.

Daud, N. M. and Husin, Z., 2004. Developing critical thinking skills in computer-aided extended reading classes. British Journal of Educational Technology, 35(4): 477-487. https:// 
doi.org/10.1111/j.0007-1013.2004.00405.x

Demir, S., 2015. Perspectives of Science teacher candidates regarding scientific creativity and critical thinking. Journal of Education and Practice, 6(17): 157-159.

Ekinci, Ö. and Aybek, B., 2010. Öğgretmen adaylarinin empatik ve eleştirel düşünme eğilimlerinin incelenmesi. İlköğretim Online, 9(2): 816-827.

Ennis, R.H., 1985. A logical basis for measuring critical thinking skills. Educational leadership, 43(2): 44-48.

Facione, P., 1990. Critical thinking: A statement of expert consensus for purposes of educational assessment and instruction (The Delphi Report).

Fong, Kim, Y., Davis, C., Hoang, T. and Kim, 2017. A meta-analysis on critical thinking and community college student achievement. Thinking Skills and Creativity, 26: 71-83. https://www.sciencedirect.com/science/ article/pii/S187118711630150X https://doi. org/10.1016/j.tsc.2017.06.002

Forst, R., 1997. Situations of the self: Reflections on Seyla Benhabib's version of critical theory. Philosophy and Social Criticism, 23(5): 79-96. https://doi.org/10.1177/019145379702300504

Gelardi, A.M. and Emby, C.E., 2005. The "Shock" factor in students' performance in accounting examinations. Advances in Accounting, 21: 219-231. https://doi.org/10.1016/S08826110(05)21009-X

Gelen, I., 2002. The evaluation of fourth grade elementary school teachers' competences about teaching thinking skills in social studies course. Cukurova University Institute of Social Sciences E-journal, 10(10): 100-119.

Ghanizadeh, A. and Mirzaee, S., 2012. Critical thinking: How to enhance it in language classes. LAP LAMBERT Academic Publishing.

Ghanizadeh, A., 2017. The interplay between reflective thinking, critical thinking, selfmonitoring, and academic achievement in higher education. Higher Education, 74(1): 101-114. https://doi.org/10.1007/s10734016-0031-y

Ghazivakili, Z., Nia, R.N., Panahi, F., Karimi, M., Gholsorkhi, H. and Ahmadi, Z., 2014. The role of critical thinking skills and learning styles of university students in their academic performance. Journal of advances in medical education and professionalism, 2(3): 95-102.
Gibbs, G., and Coffey, M., 2004. Learning and teaching in higher education. $\mathrm{CA}$ and New Delhi), 5(1): 87-100. https://doi. org/10.1177/1469787404040463

Grant, N.S., 2003. A study on critical thinking, cognitive learning style, and gender in various information science programming classes. Proceedings of the $4^{\text {th }}$ conference on information technology curriculum. pp. 96-99. https://doi. org/10.1145/947121.947142

Halpern, D.F., 1998. Teaching critical thinking for transfer across domains: Disposition, skills, structure training, and metacognitive monitoring. American psychologist, 53(4): 449. https://doi.org/10.1037/0003-066X.53.4.449

Hashemi, and Ghanizadeh, A., 2012. Critical discourse analysis and critical thinking: An experimental study in an EFL context. System, 40(1): 37-47. https://doi.org/10.1016/j. system.2012.01.009

Jenkins,A.and Walker,L.,2014.Developing student capability through modular courses. Routledge. https://doi.org/10.4324/9781315041537

Kahu, E.R. and Nelson, K., 2018. Student engagement in the educational interface: Understanding the mechanisms of student success. Higher Education Research and Development, 37(1): 58-71. https://doi.org/10. 1080/07294360.2017.1344197

Kanbay, Y. and Okanl1, A., 2017. The effect of critical thinking education on nursing students' problem-solving skills. Contemporary Nurse, 53(3): 313-321. https://doi.org/10.1080/1037 6178.2017.1339567

Kember, D., 1997. A reconceptualisation of the research into university academics' conceptions of teaching. Learning and instruction, 7(3): 255275. https://www.sciencedirect.com/science/ article/pii/S095947529600028X, https://doi. org/10.1016/S0959-4752(96)00028-X

Kennedy, M., Fisher, M.B. and Ennis, R.H., 1991. Critical thinking: Literature review and needed research. In: L. Idol, and B.P. Jones (Eds.). Educational values and cognitive instruction: Implications for reform. Lawrence Erlbaum.

King, P.M., Wood, P.K. and Mines, R.A., 1990. Critical thinking among college and graduate students. The Review of Higher Education, 13(2): 167-186. https://muse.jhu.edu/article/645100/ summary, https://doi.org/10.1353/ rhe. 1990.0026 
Lipman, M., 1988. Philosophy for children and critical thinking. Thinking: The Journal of Philosophy for Children, 7(4): 40-42. https://doi. org/10.5840/thinking19887410

Mahdyeh, N. and Arefi, M., 2014. A comparison of critical thinking, self-efficacy and academic performance among students of faculty of humanities and engineering. Indian Journal of Fundamental and Applied Life Sciences, 4(1): 153-162.

Moon, J., 2008. Critical thinking of theory and practice. In: UK Library of Congress. https:// doi.org/10.4324/9780203944882

Myers, B.E. and Dyer, J.E., 2006. The influence of student learning style on critical thinking skill. Journal of Agricultural Education, 47(1): 43. https://doi.org/10.5032/jae.2006.01043

Osborne, J., 2014. Teaching critical thinking? New directions in science education. School Science Review, 352: 53-62.

Owens, M.T., 2007. Strategy and the strategic way of thinking. Naval War College Review, 60: https://digital-commons.usnwc.edu/nwcreview/vol60/iss $4 / 10$

Paul, and Elder, 2008. Critical thinking: Strategies for improving student learning, Part II. Journal of Developmental Education, 32(2): 34-35.

Ricketts, J.C., 2003. The efficacy of leadership development, critical thinking dispositions, and student academic performance on the critical thinking skills of selected youth leaders. Doctoral dissertation, University of Florida. http://purl. fcla.edu/fcla/etd/UFE0000777

Rodrigues, A. and Oliveira, M., 2008. The role of critical thinking in physics learning. Tersedia: https://core.ac.uk/download/pdf/38301359. pdf

Ross, Loeffler, K., Schipper, S., Vandermeer, B., and Allan,G.M.,2013.Do scores on three commonly used measures of critical thinking correlate with academic success of health professions trainees? A systematic review and meta-analysis. Academic Medicine, 88(5): 724-734. https://doi. org/10.1097/ACM.0b013e31828b0823

Ruggiero, V.R., 1988. Teaching thinking across the curriculum. Harper and Row. https://doi. org/10.1002/tl.37219883405

Schraw, G., Crippen, K.J., and Hartley, K., 2006. Promoting self-regulation in science education: Metacognition as part of a broader perspective on learning. Research in Science Education, 36(1-
2): 111-139. https://doi.org/10.1007/s11165005-3917-8

Shirrell, D., 2008. Critical thinking as a predictor of success in an associate degree nursing program. Teaching and Learning in Nursing, 3(4):131-136. https://doi.org/10.1016/j.teln.2008.05.001

Shoval, E., Sharir, T., Arnon, M., and Tenenbaum, G., 2018. The effect of integrating movement into the learning environment of kindergarten children on their academic achievements. Early Childhood Education Journal, 46(3): 355-364. https://doi.org/10.1007/s10643-017-0870-x

Snyder, L.G. and Snyder, M.J., 2008. Teaching critical thinking and problem solving skills. The Journal of Research in Business Education, 50(2): 90.

Taghva, Rezaei, N., Ghaderi, J., and Taghva, R., 2014. Studying the relationship between critical thinking skills and students' educational achievement (Eghlid Universities as Case Study). International Letters of Social and Humanistic Sciences, 14: 18-25. https://doi. org/10.18052/www.scipress.com/ILSHS.25.18

Terenzini, P.T., Springer, L., Pascarella, E.T., and Nora, A., 1995. Influences affecting the development of students' critical thinking skills. Research in Higher Education, 36(1): 23-39. https://doi.org/10.1007/BF02207765

Tindal, G., and Nolet, V., 1995. Curriculum-Based Measurement in Middle and High Schools: Critical Thinking Skills in Content Areas.

Tsui, L., 2002. Fostering critical thinking through effective pedagogy: Evidence from four institutional case studies. Journal of Higher Education, 73(6): 740-763. https://doi. org/10.1353/jhe.2002.0056

Tümkaya, S., Aybek, B., and Aldağ, H., 2009. An investigation of university students' critical thinking disposition and perceived problem solving skills. Egitim Arastirmalari-Eurasian Journal of Educational Research, 36.

Tuncer, M. and Ozeren, E., 2012. Prospective teacher's evaluations in terms of using reflective thinking skills to solve problems. Procedia-Social and Behavioral Sciences, 51: 666-671. https:// doi.org/10.1016/j.sbspro.2012.08.221

Vahdat, R., Ahmadi Doyran, Z., and Zeinali, A., 2012. Relationship between critical thinking dispositions and academic achivement in urmia secondary school students. The Journal of Urmia Nursing and Midwifery Faculty, 10(1): 97-104. 
Vierra, R.W., 2014. Critical thinking: Assessing the relationship with academic achievement and demographic factors. Unpublished dissertation, University of Minnesota. https://conservancy. umn.edu/handle/11299/165155

Watson, G., and Glaser, E., 1980. Critical thinking appraisal: Forms A and B; Manual. Psychological Corporation.

Yacoubian, H.A., 2015. A framework for guiding future citizens to think critically about nature of science and socioscientific issues. Canadian Journal of Science, Mathematics and Technology Education, 15(3): 248-260. https://doi.org/10.1 080/14926156.2015.1051671

Yang,Y.T.C., and Chou,H.A.,2008. Beyond critical thinking skills: Investigating the relationship between critical thinking skills and dispositions through different online instructional strategies. British Journal of Educational Technology, 39(4): 666-684. https://doi.org/10.1111/j.1467- 8535.2007.00767.x

Yeh, Y.C., 1997. Teacher training for critical thinking instruction via a computer simulation University of Virginia.pp.1-208.https://www.learntechlib. org/p/120735/

Zayif, K., 2008. Critical thinking dispositions of teacher candidates. Unpublished Master's thesis), Abant Izzet Baysal University, Bolu.

Zeidler, D.L., Walker, K.A., Ackett, W.A., and Simmons, M.L., 2002. Tangled up in views: Beliefs in the nature of science and responses to socioscientific dilemmas. Science Education, 86(3): 343-367. https://doi. org/10.1002/sce.10025

Zemplén, G.Á., 2007. Conflicting agendas: Critical thinking versus science education in the international baccalaureate theory of knowledge course. Science and Education, 16(2): 167-196. https://doi.org/10.1007/s11191-0066387-0 